\title{
Peningkatan pengetahuan aspek perpajakan dan kualitas pengelolaan produk pada kelompok UMKM
}

\section{Yeney Widya Prihatiningtias ${ }^{1 *}$, Sri Palupi Prabandari ${ }^{2}$, Devi Nur Cahaya ${ }^{3}$, Areta Widya Kusumadewi ${ }^{4}$, Octadila Laily Anggraeni ${ }^{5}$, Karimatun Nisa, ${ }^{6}$, Ainul Rizkiyah ${ }^{7}$, Fajar Hafidh Arasy ${ }^{8}$}

\footnotetext{
${ }^{1}$ Universitas Brawijaya, Malang, Indonesia, email: yeney.wp@ub.ac.id

${ }^{2}$ Universitas Brawijaya, Malang, Indonesia, email: palupi@ub.ac.id

${ }^{3}$ Universitas Brawijaya, Malang, Indonesia, email: devinurcahaya@ub.ac.id

${ }^{4}$ Universitas Brawijaya, Malang, Indonesia, email: aretawidya@ub.ac.id

${ }^{5}$ Universitas Brawijaya, Malang, Indonesia, email: octadilaily@ub.ac.id

${ }^{6}$ Universitas Brawijaya, Malang, Indonesia, email: rim.karimah@yahoo.com

${ }^{7}$ Universitas Brawijaya, Malang, Indonesia, email: ainulrizkiyah@gmail.com

${ }^{8}$ Universitas Brawijaya, Malang, Indonesia, email: fhafidh99@gmail.com

${ }^{*}$ Koresponden penulis
}

\section{Info Artikel}

Diajukan: 03 Sept 2020

Diterima: 19 Jan 2021

Diterbitkan: 31 Jan 2021

Keywords:

community service; taxation; product management quality

Kata Kunci:

pengabdian masyarakat;

perpajakan; kualitas

pengelolaan produk

\section{Lisensi:}

cc-by-sa

\begin{abstract}
This community service activity is carried out to provide training and assistance to MSME groups that are members of the KSU Amangtiwi Malang City. This activity is carried out in relation to aspects of taxation and quality of product management, including aspects of trademark registration, food production certificates, foodstuff registration, halal label registration, and marketing methods. The hope is that these MSME players can stand up to their position in managing their products to enter the international market, as well as being orderly and obedient in tax administration. The method of implementing this activity combines online and offline to minimize the number of people gathering during the Covid-19 pandemi. The stages of the activities carried out were socialized and FGD (Focus Group Discussion) to identify initial needs; training in product management and marketing; assistance in trademark management; as well as training and assistance for MSME taxation and accounting. The activity was completed well and smoothly so that the participants were satisfied and This activity is assisted by this activity. Participants gain a better understanding of tax obligations and reporting procedures as well as an understanding of product management which includes trademark registration, SPP-IRT, BPOM and halal labels. Therefore, a follow-up program is needed so that assistance can be carried out inventively so that the participants are independent in managing their business.
\end{abstract}

\section{Abstrak}

Kegiatan pengabdian kepada masyarakat ini dilakukan untuk memberikan pelatihan dan pendampingan kepada kelompok UMKM yang tergabung dalam KSU Amangtiwi Kota Malang. Kegiatan ini dilakukan berkaitan dengan aspek perpajakan dan kualitas pengelolaan produk, termasuk didalamnya aspek pendaftaran merek dagang, sertifikat produksi pangan, pendaftaran bahan pangan, pendaftaran label halal, hingga cara pemasarannya. Harapannya, para pelaku UMKM ini dapat mandiri dalam mengelola produknya hingga masuk ke pasar internasional, serta tertib dan patuh dalam hal 


\begin{abstract}
administrasi perpajakan. Metode pelaksanaan kegiatan ini dikombinasi secara daring dan luring untuk meminimalisir jumlah orang berkumpul di masa pandemi covid-19. Tahapan kegiatan yang dilakukan adalah sosialisasi dan FGD (Focus Group Discussion) untuk mengidentifikasi kebutuhan awal; pelatihan pengelolaan dan pemasaran produk; pendampingan pengurusan merek dagang; serta pelatihan dan pendampingan perpajakan dan akuntansi UMKM. Kegiatan telah dilakukan dengan baik dan lancar. Peserta memperoleh pemahaman yang lebih baik mengenai kewajiban perpajakan dan tata cara pelaporannya serta pemahaman mengenai pengelolaan produk yang meliputi pendaftaran merek dagang, SPPIRT, BPOM dan label halal. Oleh karena ini, diperlukan program lanjutan agar pendampingan dapat dilakukan secara intensif hingga para peserta mandiri dalam mengelola usahanya.
\end{abstract}

\title{
PENDAHULUAN
}

Indonesia telah mengalami krisis ekonomi cukup parah pada 1998 yang menyebabkan jatuhnya perekonomian nasional. Banyak usaha-usaha skala besar pada berbagai sektor termasuk industri, perdagangan, dan jasa yang mengalami stagnasi bahkan sampai terhenti aktivitasnya. Namun, Usaha Mikro, Kecil, dan Menengah (UMKM) dapat bertahan dan menjadi pemulih perekonomian di tengah keterpurukan akibat krisis moneter pada berbagai sektor ekonomi.

Kegiatan UMKM merupakan salah satu bidang usaha yang dapat berkembang dan konsisten dalam perekonomian nasional. Data Dinas Koperasi dan UMKM menunjukkan total nilai Produk Domestik Bruto (PDB) Indonesia mencapai Rp12.840,8 triliun, meningkat sebesar 9,63\% dari tahun 2016 serta memberikan kontribusi sebesar Rp7.704,6 triliun atau 60\% dari total PDB Indonesia (Kementerian Koperasi dan Usaha Kecil dan Menengah, 2019). Jumlah populasi UMKM Indonesia pada tahun 2017 mencapai 62,92 juta unit usaha dimana hal tersebut mengalami peningkatan dari tahun 2016 sebesar 2,06\%. Jumlah tenaga kerja sebanyak 116,67 juta orang atau 97,02\% terhadap seluruh tenaga kerja di Indonesia (Kementerian Koperasi dan Usaha Kecil dan Menengah, 2018). Data tersebut menunjukkan bahwa peranan UMKM dalam perekonomian Indonesia sangat penting dalam peningkatan penyediaan lapangan pekerjaan dan diharapkan mampu menopang perekonomian Indonesia.

Kota Malang merupakan salah satu wilayah dengan peningkatan jumlah UMKM tertinggi di Jawa Timur dengan jumlah unit usaha pada tahun 2017 sekitar 113.000 unit usaha. Penyebaran sektor pada UMKM Kota Malang terdiri dari perdagangan, hotel dan restoran, kerajinan, jasa-jasa, industri pengolahan, transportasi, dan pertanian (Badan Pusat Statistik, 2018). $\mathrm{Hal}$ tersebut menunjukkan bahwa banyak potensi usaha yang dapat dikembangkan melalui paguyuban-paguyuban yang tersebar di Kota Malang demi penguatan ekonomi masyarakat.

Koperasi Serba Usaha Amangtiwi (KSU Amangtiwi) adalah salah satu paguyuban UMKM di Kota Malang. KSU Amangtiwi membawahi 300 usaha mikro dan menengah (UMM) di Malang Raya yang bertujuan untuk membantu para pelaku UMKM mengenalkan produk-produk mereka ke masyarakat. 
Kegiatan yang biasa dilakukan oleh KSU Amangtiwi diantaranya menyediakan galeri yang terletak di Pasar Bareng untuk memperkenalkan produk UMM anggotanya. Selain itu, KSU Amangtiwi juga melakukan pemberian saran pengemasan produk yang praktis dan menarik, pencarian tempat untuk mengenalkan produk anggotanya, pelatihan digital marketing, dan membantu pembuatan logo produk.

Dikutip dari artikel CNBC Indonesia (2019), menurut Presiden Joko Widodo, salah satu penyebab UMKM tidak dapat berkembang adalah kurangnya kemampuan UMKM dalam membangun brand, desain yang mengikuti pasar dan membuat kemasan yang menarik. Hal tersebut juga yang dirasakan oleh ketua KSU Amangtiwi, Mei Ridhowati yang mengatakan bahwa anggotanya mengalami kesulitan dalam hal pengelolaan produk utamanya terkait strategi pemasaran.

Manajemen pemasaran merupakan suatu hal yang sangat penting untuk semua perusahaan, baik dalam Usaha Besar (UB) maupun UMKM. Penerapan manajemen pemasaran ini sendiri berkaitan dengan kemampuan usaha dalam menjangkau pasar dan memaksimalkan peluang yang dimiliki. Penerapan manajemen pemasaran yang menarik dan memaksimalkan keunggulan kompetitif diharapkan akan mampu memperkuat posisi unit usaha dalam menghadapi tantangan dan persaingan serta dapat memanfaatkan setiap peluang yang ada dan pada akhirnya akan memberi nilai tambah bagi usaha.

Di sisi perpajakan, pemerintah juga telah mendorong pertumbuhan UMKM melalui penurunan tarif pajak bagi UMKM dari $1 \%$ menjadi $0,5 \%$ dari penghasilan bruto melalui PP No 23 Tahun 2018. Cara penghitungan pajak yang sederhana juga diharapkan dapat mendorong UMKM untuk lebih memaksimalkan potensinya dan terus berkembang. Pemerintah juga mendorong UMKM untuk dapat menjual produknya ke luar negeri (ekspor) dan diberikan fasilitas PPN ekspor $0 \%$. Direktorat Jenderal Pajak (DJP) menyampaikan bahwa Penerimaan pajak dari sektor UMKM masih cukup rendah, hanya mencapai $0,43 \%$ dari jumlah penerimaan pajak, padahal jumlah pelaku UMKM mencapai $65 \%$ dari jumlah pelaku usaha di Indonesia secara keseluruhan (MUC Consulting, 2019). Motivasi para pelaku UMKM dirasa kurang untuk mempelajari mengenai perpajakan karena mereka beranggapan bahwa hal tersebut hanya dapat dilakukan oleh usaha-usaha besar saja sehingga menyebabkan usaha mereka tidak berkembang dan tidak naik kelas. UMKM membutuhkan peran akademisi untuk memberikan pelatihan dan pendampingan terkait aspek perpajakan dan manajemen produk.

Mitra pada kegiatan pengabdian ini adalah KSU Amangtiwi. Berdasarkan analisis situasi di atas, hasil wawancara pendahuluan dengan pelaku UMKM dan pengurus KSU Amangtiwi, permasalahan utama yang dihadapi oleh mitra adalah kurangnya pemahaman pelaku UMKM terkait pengelolaan produk serta strategi pemasaran yang berdampak pada kurang maksimalnya tingkat penjualan produk UMKM dan pengetahuan tentang pencatatan dan pelaporan perpajakan. 
Salah satu solusi dalam mengatasi permasalahan tersebut di atas adalah dengan memberikan pelatihan tentang perpajakan dan perbaikan manajemen pemasaran produk bagi pelaku UMKM agar pelaku UMKM lebih memahami dan taat dalam pemenuhan kewajiban perpajakannya serta meningkatkan pengelolaan produk sehingga produknya lebih dikenal yang pada akhirnya dapat meningkatkan penjualan produk UMKM. Peningkatan nilai penjualan UMKM secara tidak langsung berpengaruh terhadap peningkatan penerimaan dan roda perekonomian negara melalui UMKM.

\section{METODE PELAKSANAAN}

Kegiatan pengabdian dilaksanakan pada bulan Mei 2020 hingga September 2020. Pengabdian dilaksanakan secara kombinasi daring dan luring dikarenakan untuk meminimalisir jumlah orang berkumpul, mengingat pengabdian dilaksanakan pada masa pandemi covid-19. Kegiatan pengabdian dibagi ke dalam beberapa tahapan sebagai berikut:

1. Sosialisasi dan FGD (Focus Group Discussion).

2. Pelatihan Pengelolaan dan Pemasaran Produk.

3. Pendampingan Pengurusan Merek Dagang.

4. Pelatihan dan Pendampingan Perpajakan dan Akuntansi UMKM.

Keempat aktivitas tersebut diharapkan dapat menjadi sebuah tahapan yang berkesinambungan untuk kemudian dapat memberdayakan anggota KSU secara lebih maksimal. Aspek perpajakan menjadi fokus kegiatan pada tahapan terakhir dalam rangkaian ini karena faktor manajemen produk perlu diperkuat terlebih dahulu sebelum memasuki fase ketaatan terkait peraturan perpajakan. Manajemen produk dalam aktivitas ini terdiri dari pengurusan label halal, pendaftaran ke BPOM dan juga SPP-IRT.

\section{HASIL DAN PEMBAHASAN}

Kegiatan pengabdian kepada masyarakat (PkM) ini dilaksanakan melalui beberapa tahapan, yaitu: 1) rapat koordinasi bersama tim pelaksana PkM, 2) melakukan kontak awal dan konfirmasi dengan pihak KSU Amangtiwi, 3) membuat perjanjian kerjasama antara ketua pelaksana PkM dengan kepala KSU Amangtiwi, 4) focus group discussion, 5) pelatihan pada aspek perpajakan, pemasaran, dan merek dagang yang dihadiri 26 pelaku UMKM dan 3 (tiga) orang Narasumber, 6) pendampingan pengurusan perpajakan, pemasaran, dan pendaftaran merek dagang, dan 7) pembuatan modul panduan aspek perpajakan.

Mitra pada kegiatan PkM ini adalah KSU Amangtiwi yang beranggotakan pengusaha UMKM di Kota Malang dengan jenis usaha yang berbeda-beda meliputi produsen makanan, minuman, frozen food, hingga fashion and craft. Kegiatan Focus Group Discussion diikuti oleh 15 perwakilan anggota KSU Amangtiwi. 


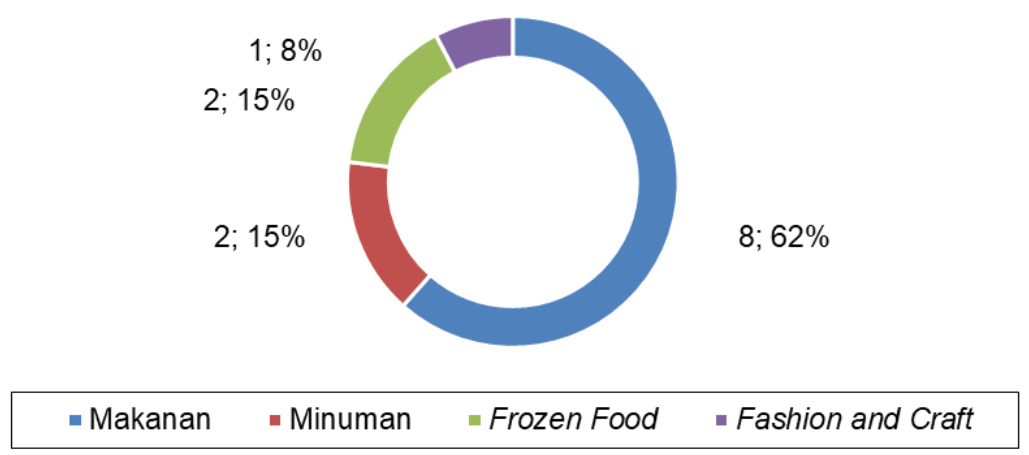

Gambar 1. Demografi peserta focus group discussion

Adapun tujuan dari kegiatan ini adalah memberikan tambahan wawasan, pemahaman, dan solusi terkait dengan permasalahanpermasalahan pada tiga aspek tersebut. Berikut ini merupakan hasil dan pembahasan pada masing-masing aspek.

\section{Aspek Perpajakan}

Salah satu aspek yang menjadi fokus pengabdian kepada masyarakat KSU Amangtiwi adalah aspek perpajakan. Terdapat beberapa hal yang mendasari tingkat kepatuhan wajib pajak dalam melaksanakan kewajiban perpajakannya, antara lain sosialisasi perpajakan dari petugas pajak dan tingkat pemahaman wajib pajak terhadap aturan perpajakan, serta lemahnya pengetahuan tentang keadilan pajak (Muniroh \& Azizi, 2019). Selain itu, tarif pajak juga mempengaruhi tingkat kepatuhan wajib pajak (Inasius, 2015). Para pelaku UMKM yang tergabung dalam KSU Amangtiwi ini telah memiliki kesadaran yang tinggi terhadap kepatuhan pajak. Hal ini dibuktikan dengan terdaftarnya semua UMKM dalam KSU Amangtiwi sebagai wajib pajak dengan klasifikasi usaha perseorangan. Namun, sangat disayangkan hal ini tidak diiringi dengan pemahaman yang cukup akan perpajakan UMKM.

Kurangnya pemahaman terhadap perpajakan ini disebabkan oleh beberapa hal, antara lain kurangnya pengetahuan wajib pajak UMKM terhadap aturan serta kurangnya sosialisasi perpajakan dari petugas pajak. Hal ini diungkapkan oleh pelaku UMKM dalam kegiatan Focus Group Discussion (FGD) Peningkatan Ketaatan dalam Aspek Perpajakan dan Kualitas Pengelolaan Produk serta Kemasan pada Kelompok UMKM Kota Malang" pada Selasa, 23 Juni 2020, di UB Guest House, Kota Malang (lihat Gambar 2). Para pelaku UMKM yang dalam kegiatan tersebut baru mengetahui aspek perpajakan UMKM setelah diadakan FGD tersebut, yang meliputi bagaimana cara menghitung, membayar, hingga melaporkan pajaknya. Sosialisasi peraturan perpajakan UMKM selama ini dinilai belum sepenuhnya menyentuh seluruh wajib pajak UMKM. Selama ini, beberapa pelaku UMKM hanya mengandalkan 
Account Representative (AR) di kantor pajak, sedangkan sisanya tidak melakukan kewajiban perpajakannya. Pelaku UMKM akan meminta AR untuk menyelesaikan semua kewajiban perpajakan mulai dari pencatatan keuangan sederhana, pembayaran pajak, hingga pelaporan pajaknya.

Pada kegiatan Focus Group Discussion diketahui bahwa beberapa peserta pelaku UMKM belum sepenuhnya memahami tata cara pembayaran pajak, seperti yang disampaikan oleh Bapak Heri (pelaku UMKM), "Saya baru tahu tentang pajak, informasi atau sosialisasi yang seperti ini belum sampai kepada kami bahwa ternyata boleh memilih opsi pembayaran pajak UMKM. Saya harap nanti kami diajari tentang perhitungan pajak agar kami juga bisa mengabdi kepada Negara."

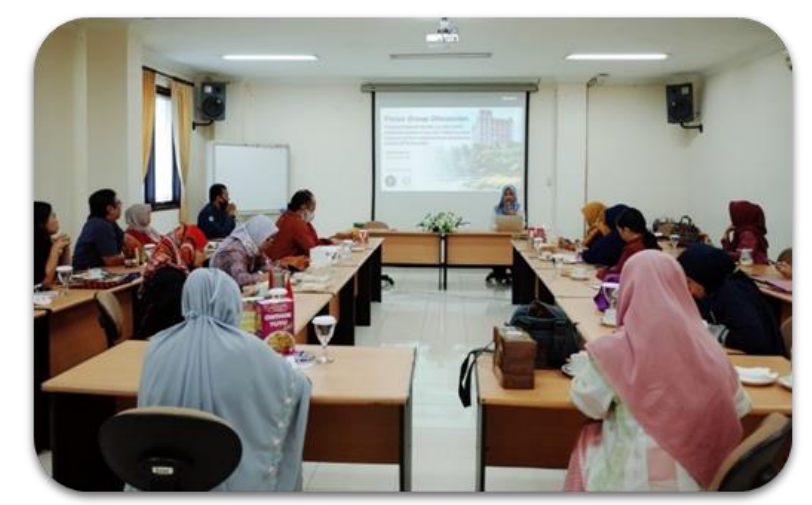

Gambar 2. Focus Group Discussion dengan KSU Amangtiwi dengan menerapkan protokol kesehatan

Para pelaku UMKM ini sangat berharap nantinya dapat secara mandiri memahami mengenai aspek perpajakan, mulai dari menghitung, membayar, hingga melaporkan pajak, tanpa bergantung sepenuhnya kepada AR. Saat ini, UMKM dengan omzet di bawah 4,8 milyar berkewajiban untuk membayar pajak sesuai skema Peraturan Pemerintah Republik Indonesia Nomor 46 Tahun 2013 yang telah diperbarui dengan Peraturan Pemerintah Nomor 23 Tahun 2018 tentang Pajak Penghasilan atas Penghasilan Dari Usaha yang Diterima atau Diperoleh Wajib Pajak yang Memiliki Peredaran Bruto Tertentu. Tarif yang dikenakan adalah $0,5 \%$ dari peredaran bruto untuk total peredaran bruto di bawah 4,8 milyar. Meskipun tarif ini telah turun dari tarif sebelumnya sebesar $1 \%$, namun pelaku UMKM ini masih merasa berat karena dasar pengenaan pajaknya adalah peredaran bruto. Namun disisi lain, pelaku UMKM ini memiliki semangat yang tinggi untuk tertib dan patuh dalam administrasi perpajakan karena ingin berkontribusi kepada negara sebagai warga negara yang baik.

Penerapan Peraturan Pemerintah Nomor 23 Tahun 2018 ini sebenarnya memberikan kemudahan dalam administrasi perpajakan. Pelaku UMKM cukup mencatat secara sederhana daftar peredaran bruto usahanya setiap bulan. Total pajak terutang dihitung dengan mengalikan 
peredaran bruto tersebut dengan tarif $0,5 \%$ tiap bulannya. Pembayaran pajak ini dapat dilakukan di bank persepsi, kantor pos, ataupun secara online menggunakan internet banking dengan membuat Kode Billing melalui aplikasi e-Billing (SSE) terlebih dahulu. Pajak terutang yang disetorkan sendiri oleh wajib pajak, harus disetor paling lambat tanggal 15 bulan berikutnya setelah Masa Pajak berakhir.

\section{Aspek Pendaftaran Merek Dagang, Sertifikat Produksi Pangan, Pendaftaran Bahan Pangan, Pendaftaran Label Halal}

Selain permasalahan tentang aspek perpajakan para pelaku UMKM memiliki permasalahan terkait dengan pendaftaran merek dagang ke Direktorat Jenderal Kekayaan Intelektual (DJKI). Hasil penelitian Salleh et al. (2017) menunjukkan bahwa branding dapat meningkatkan kinerja UMKM. Salah satu bentuk branding yang dapat dilakukan yaitu melalui pendaftaran merek dagang. UMKM yang memiliki merek dagang sendiri akan lebih mandiri dan dapat mengembangkan pemasarannya dengan lebih baik. Berdasarkan hasil focus group discussion (FGD) yang telah dilaksanakan (23 Juni 2020, UB Guest House, Malang), terdapat beberapa pelaku UMKM yang masih belum peduli tentang pentingnya merek dagang demi kelangsungan usaha mereka dan beberapa diantaranya mengeluhkan sulitnya untuk mendaftarkan produk mereka pada website DJKI. Salah satu pelaku UMKM mengaku bahwa telah berkali-kali mecoba mendaftrakan produknya bahkan hingga merubah nama produknya, namun masih belum bisa mendapatkan persetujuan dari DJKI. Alasan merek dagang tersebut ditolak karena masih menggunakan kata atau kalimat baku baik dalam bahasa Indonesia maupun bahasa Inggris. Oleh karena itu perlu diberikan pemahaman terkait dengan pengurusan pendaftaran merek dagang.

Hasil dari pelatihan yang telah dilaksanakan adalah bahwa sangat penting untuk mengurus Hak atas Kekayaan Intelektual (HKI) merek dagang. Kelas Merek terdiri dari 45 kelas barang dan jasa. Pemberian nama merek sendiri harus spesifik pada jenis produk dan harus berbeda antar produk sejenis. Terdapat beberapa alasan yang berpotensi menolak merek dagang, yaitu 1) merek yang bertentangan dengan ideologi negara, Peraturan Perundang-undangan, moralitas, agama, kesusilaan, atau ketertiban umum, 2) permohonan ditolak karena merek tersebut memiliki persamaan pada pokok atau keseluruhan terhadap merek lain yang sudah terdaftar terlebih dahulu.

Selain pengurusan merek dagang, ternyata para pelaku UMKM masih kurang memahami pentingnya Sertifikat Produksi Pangan Industri Rumah Tangga (SPP-IRT), pendaftaran bahan pangan ke BPOM RI, dan pembuatan sertifikat (label) halal pada produk. SPP-IRT merupakan sertifikat perijinan yang memungkinkan UMKM memiliki ijin edar atas produk yang dihasilkan. Hal tersebut berpengaruh secara tidak langsung pada daya saing produk (Nizar \& Mashuri, 2018; Suhardiyah et al., 2020). Sehingga pelatihan yang diberikan bukan hanya pada aspek merek 
dagang saja, namun juga tiga aspek penting lainnya tersebut. Berdasarkan hasil pelatihan yang telah dilaksanakan pada 28 Juli 2020 di Fakultas Ekonomi dan Bisnis, Universitas Brawijaya, Malang, menurut Narasumber (Dr. Sucipto, STP., MP., IPU.), SPP-IRT diperuntukkan bagi Industri Rumah Tangga (IRT) yang memiliki segmen lebih kecil jika dibandingkan sertifikasi BPOM RI (lihat Gambar 3). Selain itu, IRT ini juga berbentuk pangan yang bukan pangan berkhasiat (seperti jamu dan obatobatan). SPP-IRT memiliki masa berlaku selama 5 (lima) tahun dan dapat diperpanjang kembali selambat-lambatnya 3 (tiga) bulan sebelum masa berakhir. Berkaitan dengan hal tersebut, pengusaha harus lolos dalam beberapa ujian (tes) untuk medapatkan sertifikat keamanan dan pemeriksaan sarana produksi tersebut. Pengusaha harus terdaftar dalam SPP-IRT atau BPOM RI terlebih dahulu, sebagai syarat jika ingin mengajukan sertifikasi halal. Terdapat aturan hukum yang mengatur tentang pangan yang harus dipenuhi beberapa aspeknya yaitu aman, higienis, bermutu, bergizi, tidak bertentangan dengan agama, keyakinan, budaya masyarakat, sanitasi, dan kebersihannya (Putri et al., 2015).

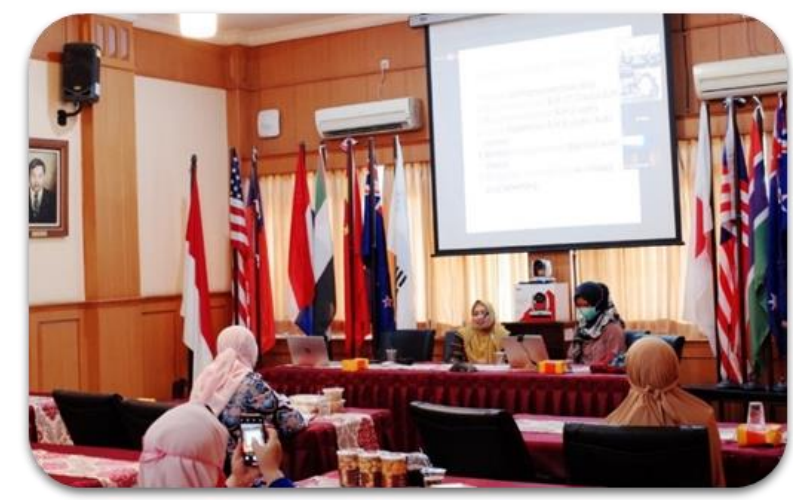

Gambar 3. Pelatihan manajemen produk dengan mengaplikasikan protokol kesehatan

Selanjutnya adalah terkait dengan pendaftaran bahan pangan ke BPOM RI. Pengurusan izin ke BPOM RI harus memenuhi beberapa persyaratan yang lebih ketat. Persyaratan tersebut mulai dari administrasi, proses produksi, produk yang telah tersertifikasi Standar Nasional Indonesia (SNI), risiko bahan pangan, dan lain-lain. Berkaitan dengan hal tersebut, izin BPOM RI ini lebih diperuntukan untuk kelompok industri yang lebih besar, produk yang memiliki khasiat, dan produk yang memiliki risiko lebih tinggi. Industri yang telah terdaftar dalam SPP-IRT, akan ada laporan tersendiri kepada pihak BPOM.

Setelah melakukan pengurusan SPP-IRT dan mendapat sertifikat dari BPOM RI, maka selanjutnya dapat melakukan pengurusan sertifikat halal agar dapat mencantumkan label halal pada kemasan produk. terdapat 2 (dua) motivasi utama produsen jika ingin mendapatkan sertifikasi halal, yaitu motivasi pada peluang bisnis dan motivasi pada 
keimanan. Dengan mayoritas penduduk Indonesia adalah muslim, maka adanya label halal diharapkan produk memiliki kekuatan dan mampu menembus pasar yang lebih besar berkaitan dengan produk halal. Terdapat beberapa sistem prasyarat untuk menghasilkan produk halal, yaitu mulai dari masukan (input), proses (process), dan keluaran (output), sehingga diperlukan prosedur yang halal pula untuk memproses produk agar mendapatkan sertifikat halal. Selain itu, nama produk yang dicantumkan harus dengan nama yang baik dan tidak mengarah terhadap nama yang dilarang oleh agama. Penafsiran kehalalan suatu produk dapat dilihat dari perspektif suatu barang, seperti bahan-bahan yang digunakan untuk membuat produk (faktor internal) dan bagaimana cara memperoleh modal, bahan, alat, dan lain sebagainya (faktor eksternal) (Ahmad et al., 2013; Sahir et al., 2016; Verbeke et al., 2013).

\section{Aspek Pemasaran}

Salah satu aspek yang menjadi perhatian adalah pemasaran. Pengusaha harus memperhatikan peluang dan tantangan guna mengambil kesempatan. Dalam hal ini, para pelaku UMKM dituntut untuk selalu berinovasi dengan kreatif agar dapat memenuhi kebutuhan pasar, sehingga usahanya dapat bertahan. Selain itu, aspek pemahaman digital juga sangat penting untuk memasarkan produk, seperti pemasaran melalui media sosial agar dapat menekan biaya pemasaran (Evasar et al., 2019; Haptari \& Nugroho, 2019; Harto et al., 2019).

Manajemen pemasaran merupakan suatu hal yang sangat penting untuk semua perusahaan, termasuk UMKM. Penerapan manajemen pemasaran ini sendiri berkaitan dengan kemampuan usaha dalam menjangkau pasar dan memaksimalkan peluang yang dimiliki. Penerapan manajemen pemasaran yang menarik dan memaksimalkan keunggulan kompetitif diharapkan akan mampu memperkuat posisi unit usaha dalam menghadapi tantangan dan persaingan serta dapat memanfaatkan setiap peluang yang ada dan pada akhirnya akan memberi nilai tambah (value added) bagi usaha.

Sebagian besar UMKM yang tergabung dalam KSU Amangtiwi telah memiliki akses yang cukup baik terhadap platform pemasaran online, beberapa diantaranya telah memulai memasarkan produknya melalui media sosial instagram, beberapa lainnya juga telah memiliki toko online di beberapa marketplace seperti tokopedia, shopee, dan bukalapak. Salah seorang pelaku UMKM berharap, bahwa Universitas Brawijaya melalui kegiatan pengabdian masyarakat ini dapat membantu pemasaran produk UMKM dengan membuat link berdomain ub.ac.id dan website pemerintahan. Hal ini penting bagi UMKM karena dengan domain website pemerintah, jangkauan pemasaran akan lebih luas.

Universitas Brawijaya, khususnya Fakultas Ekonomi dan Bisnis memiliki Laboratorium Kewirausahaan, sehingga dapat menjadi wadah bagi para UMKM ini untuk menjalin kerjasama dalam memasarkan produknya. Melalui fasilitas yang dimiliki, UMKM dapat dibantu untuk 
memasarkan produknya pada website dengan domain ub.ac.id dan kemudian terhubung dengan akun media sosial dan toko online UMKM. Dengan adanya kegiatan ini, para pelaku UMKM KSU Amangtiwi juga berharap untuk diadakan pelatihan-pelatihan selanjutnya karena masih banyak sekali pengetahuan yang harus digali dan akses kemudahan untuk mengembangkan produknya.

\section{KESIMPULAN}

Pelaksanaan kegiatan pengabdian kepada masyarakat dalam rangka peningkatan ketaatan aspek perpajakan dan kualitas pengelolaan produk pada KSU Amangtiwi sangat membantu pelaku usaha dalam hal meningkatkan ketaatan wajib pajak UMKM yang telah terdaftar serta melindungi kelangsungan usaha para UMKM hingga nantinya dapat berkembang besar dalam pasar Internasional.

Dengan dilakukannya sosialisasi, wawasan, dan pemahaman yang cukup dalam hal administrasi perpajakan, pelaku UMKM pada KSU Amangtiwi tidak lagi mengalami kesulitan dalam hal pemenuhan kewajiban perpajakan yang mana selama ini masih rendah. Sosialisasi dan pendampingan pengelolaan produk yang meliputi pendaftaran merek dagang, sertifikat produksi pangan, pendaftaran bahan pangan, pendaftaran label halal, membuka peluang bagi pelaku UMKM untuk menjangkau pasar yang lebih luas. Hal tersebut tentunya didukung dengan pelatihan terkait strategi pemasaran yang tepat. Para pelaku UMKM ini memiliki motivasi yang tinggi untuk mengabdi menjadi warga negara Indonesia yang baik serta berkontribusi melalui roda perekonomian sebagai UMKM sekaligus wajib pajak yang patuh. Hal ini akan menjadi peluang untuk meningkatkan penerimaan dan roda perekonomian negara melalui UMKM.

Terdapat beberapa keterbatasan pada kegiatan pengabdian kepada masyarakat ini antara lain:

1. Mitra pengabdian adalah KSU Amangtiwi yang berada di Kota Malang dimana permasalahan yang dihadapi oleh pelaku UMKM tidak dapat digeneralisasi pada kelompok UMKM lain. Disarankan kegiatan pengabdian selanjutnya dapat dilakukan pada kelompok UMKM yang memiliki jangkauan yang lebih luas.

2. Bentuk kegiatan pengabdian berikutnya dapat lebih mendalam terkait dengan jaringan pemasaran produk sehingga produk yang dihasilkan oleh UMKM dapat lebih dikenal oleh masyarakat.

\section{UCAPAN TERIMA KASIH}

Terima kasih kepada Lembaga Penelitian dan Pengabdian Masyarakat Universitas Brawijaya yang telah memberikan kesempatan dalam melaksanakan pengabdian masyarakat melalui Program Doktor Mengabdi tahun 2020. Selain itu juga terima kasih kepada KSU Amangtiwi atas diberikannya akses untuk pelaksanaan kegiatan pengabdian kepada masyarakat ini. 


\section{DAFTAR RUJUKAN}

Ahmad, M., Kadir, S. A., \& Salehuddin, N. A. (2013). Perceptions and Behaviour's of Muslims and Non-Muslims Towards Halal Products. Journal of Social and Development Sciences, 4(6), 249-257. https://doi.org/10.22610/jsds.v4i6.759

Badan Pusat Statistik. (2018). Usaha Mikro Kecil Kota Malang. Website. https://malangkota.bps.go.id/

Evasar, A. D., Utomo, Y. B., \& Ambarwati, D. (2019). Pelatihan dan Pemanfaatan E-Commerce sebagai Media Pemasaran Produk UMKM di Desa Tales Kecamatan Ngadiluwih, Kabupaten Kediri. Cendekia: Jurnal Pengabdian Masyarakat, 1(2), 75-84. https://doi.org/http://dx.doi.org/10.32503/Cendekia.v1i2.603

Farras, B. (2019). UMKM Kalah Saing, Jokowi Beberkan Masalahnya. CNBC Indonesia. https://www.cnbcindonesia.com/news/20190111134416-450214/umkm-kalah-saing-jokowi-beberkan-masalahnya

Haptari, V. D., \& Nugroho, R. (2019). Literasi Akuntansi dan Pemasaran Online bagi UMKM Desa Tirtonirmolo Kabupaten Bantul. Jurnal KUAT: Keuangan Umum Dan Akuntansi Terapan, 1(3), 190-193. https://doi.org/http://dx.doi.org/10.31092/kuat.v1i3.632

Harto, D., Pratiwi, S. R., Utomo, M. N., \& Rahmawati, M. (2019). Penerapan Internet Marketing dalam Meningkatkan Pendapatan pada UMKM. JPPM: Jurnal Pengabdian Dan Pemberdayaan Masyarakat, 3(1), 3945. https://doi.org/http://dx.doi.org/10.30595/jppm.v3i1.3033

Inasius, F. (2015). Tax Compliance of Small and Medium Enterprises: Evidence from Indonesia. Accounting \& Taxation, 7(1), 67-73. https://papers.ssrn.com/sol3/papers.cfm?abstract_id=2653880

Kementerian Koperasi dan Usaha Kecil dan Menengah. (2018). Perkembangan Data Usaha Mikro, Kecil, Menengah (UMKM) dan Usaha Besar (UB) Tahun 2016 - 2017. Website.

Kementerian Koperasi dan Usaha Kecil dan Menengah. (2019). Laporan Rapat Kerja Nasional 2019: Sinergitas Pengembangan KUMKM melalui Penguatan Peran Antar Lembaga. Laporan Rapat Kerja Nasional 2019.

MUC Consulting. (2019). Kontribusi Pajak UMKM Masih Sangat Rendah. Mucglobal.Com.

Muniroh, H., \& Azizi, Z. W. (2019). Faktor-faktor yang Mempengaruhi Kepatuhan Wajib Pajak Final PP No 46 Tahun 2013 pada UMKM di Kabupaten Rembang. Jurnal Akuntansi Indonesia, 8(1), 27-38. https://doi.org/http://dx.doi.org/10.30659/jai.8.1.27-38

Nizar, M., \& Mashuri, M. (2018). Pengembangan Potensi Lokal Melalui Pemberdayaan Lingkungan dan UMKM pada Masyarakat Pesisir. Jurnal Soeropati, $1(1)$, 41-56. https://jurnal.yudharta.ac.id/v2/index.php/soeropati/article/view/1241

Putri, R. A. I., Rohayati, Y., \& Aisha, A. N. (2015). Evaluasi Pemenuhan Kriteria CPPB-IRT dan Sertifikasi Halal Pada UKM Pelangi Rasa. Jurnal Rekayasa Sistem Dan Industri, 2(3), 17-24. 
https://doi.org/https://doi.org/10.25124/jrsi.v2i03.60

Sahir, S. H., Ramadhani, A., \& Tarigan, E. D. S. (2016). Pengaruh Gaya Hidup, Label Halal, dan Harga Terhadap Keputusan Pembelian Kosmestik Wardah pada Mahasiawa Progam Studi Manajemen Fakultas Ekonomi Universitas Medan Area Medan. Jurnal Konsep Bisnis Dan Manajemen, $3(1)$, $1-15$. https://doi.org/https://doi.org/10.31289/jkbm.v3i1.237

Salleh, M., Sulaiman, M., Haque, E., \& Othman, A. K. (2017). Impact Of Branding On SME Performance. Journal of Islamic Management Studies, $1(1)$ $15-28$. http://publications.waim.my/index.php/jims/article/view/5

Suhardiyah, M., Widodo, U. P. W., \& Sasmita, Y. (2020). Legalisasi Dan Pengelolaan Usaha Pada UMKM. Ekobis Abdimas: Jurnal Pengabdian Masyarakat, 1(1),

45-53. https://doi.org/10.36456/ekobisabdimas.1.1.2340

Verbeke, W., Rutsaert, P., Bonne, K., \& Vermeir, I. (2013). Credence Quality Coordination and Consumers' Willingness-to-Pay for Certified Halal Labelled Meat. Meat Sci, 95(4), 790-797. https://doi.org/https://doi.org/10.1016/j.meatsci.2013.04.042 